В.В. БОРИСЕНКО

\title{
МОДЕЛЬ ФОРМУВАННЯ ЗДОРОВ'ЯЗБЕРЕЖУВАЛЬНОЇ КОМПЕТЕНТНОСТІ МАЙБУТНІХ ФАХІВЦІВ ТЕХНІЧНИХ СПЕЦІАЛЬНОСТЕЙ В УМОВАХ НЕФОРМАЛЬНОЇ ОСВІТИ
}

\author{
(C) Борисенко В.В., 2019 \\ http://orcid.org/0000-0003-0214-5632 \\ http://doi.org/10.34142/2312-2471.2019.62.04
}

У статті подано теоретично обгрунтовану модель формування здоров'язбережувальної компетентності студентів технічних спеціальностей в умовах неформальної освіти засобами фізичного виховання, яка базується на сукупності загальнодидактичних (науковості; системності й послідовності; доступності; зв'язку навчання $з$ життям; свідомості та діяльності; наочності; міцності знань, умінь та навичок; індивідуального підходу) та специффічних принц̧ипів (формування базових компетентностей з основ охорони здоров'я: гуманістичної спрямованості, свідомої перспективи, орієнтації на самостійну роботу, інтеграції навчання, інтерактивності, ініціативності, побудови індивідуальної оздоровчої системи; неформального фізичного виховання: аксіологічний, побудови фізичної культури та оздоровчого середовища ЗВО, ергономічний, редукційний, орієнтаџї на формування ефективності та здоров'я фахівия). Це передбачає вдосконалення змісту професійної підготовки майбутніх фахівців технічних спеціальностей з питань охорони здоров'я разом із використанням форм (перерви для фізичних вправ; спортивні секиії, аеробіка, шейпінг, фітнес, басейн, тренажерний зал тощь; масові фізкультурно-спортивні заходи змагального характеру; масові фізкультурно-спортивні заходи (спортивні флешмоби, туристичні походи, масові гуляння з нагоди державних та регіональних свят тощо), спрямовані на розвиток особистих якостей та мотивації до здорового способу життя; науково-практичні конференції для студентської молоді з питань охорони здоров'я; студентські змагання та інтелектуальні змагання з охорони здоров'я), методи (створення ситуацій зацікавленості, методи проєктів, бесіди) та засоби (набори вправ, щзоденники охорони здоров'я, цчифрові технології здоров'я) неформальної освіти, які відбираються з урахуванням досягнень фізичного виховання у напрямку ведення здорового способу життя та здоров'я.

Ключові слова: здоров'язбережувальна компетентність; формування здоров'язбережувальної компетентності; майбутні фахівці з технічних спеціальностей; засоби фізичного виховання; неформальна освіта; професійна підготовка; модель. 
Borisenko A. I. Model of Health-Careing Competence Formation for Future Specialists of Technical Specialties in Conditions of Non-Formal Education by Means of Physical Education

The article develops and substantiates theoretically the model of healthpreserving competence formation for students of technical specialties in the conditions of non-formal education by means of physical education, which is based on a set of general didactic (scientific; system and sequence; accessibility; connection of learning with life; consciousness and activity; clarity; strength of knowledge, skills and abilities; individual approach) and specific principles (formation of basic competencies on the basics of health care: humanistic orientation, conscious perspective, focus on independent work, integration of learning, interactivity, initiative, self-regulation, building an individual health system; informal physical education: axiological, construction of physical culture and health environment at universities, ergonomic, reduction, focus on the formation of efficiency and health of the specialist). It provides the improvement to the content of professional training of future technicians specialties in health issues together with the use of forms (exercise breaks; sports sections, aerobics, shaping, fitness, swimming pool, gym, etc; mass physical culture and sports events ("Heroic Games" "Patriot Games", "Knight's Tournaments", "Cossack Fun”, "Sports Days”, sports holidays, festivals, sports contests, tournaments, etc.) of a competitive nature; mass physical culture and sports events (sport flash mobs, tourist hikes, mass festivities on the occasion of state and regional holidays, etc.). They are aimed to developing personal qualities and motivation for a healthy lifestyle; as well as scientific and practical conferences for student youth on health issues; student competitions and intellectual competitions on health care), methods (creation of situations of interest, project methods, conversations) and means (sets of exercises, health diaries, digital health technologies) of non-formal education, which are selected taking into account the achievements of physical education in the direction of leading a healthy lifestyle and health.

Keywords: health competence; health-preserving competence formation; future specialists in technical specialties; means of physical education; non-formal education; professional training; model.

Постановка проблеми. Одним із завдань ефективної підготовки фахівців у ЗВО є створення умов для інтенсивної та напруженої творчої розумової праці без перевантаження і перевтоми, у поєднанні з активним відпочинком та фізичним удосконаленням. Цій вимозі повинно відповідати таке використання засобів фізичного виховання, яке сприяло б підтриманню досить високої та стійкої навчальної та трудової активності і працездатності студентської молоді, допомагало б їм краще виконувати навчальні завдання та здійснювати професійну діяльність у майбутньому.

Особливо це стосується фахівців технічних спеціальностей, оскільки умови їх праці спричиняють зростання рівня професійних хвороб (вібраційної 
хвороби; захворювань периферичної нервової системи, що пов'язано зі значним динамічним і статичним напруженням верхніх кінцівок, вимушеною робочою позою, переохолодженням, однотиповими рухами рук тощо; приглухуватості) та містять шкідливі виробничі фактори (вплив пилу, вібрації, шуму, важкість та напруженість праці).

Водночас формальна освіта не спроможна повноцінно забезпечити ці потреби студентів технічних спеціальностей, оскільки переважно зорієнтована на надання академічних знань. Натомість неформальна освіта $є$ більш гнучкою, адаптивно спрямованою на сучасні інноваційні процеси й у такий спосіб відкриває студенту нові можливості розвитку і саморозвитку, зокрема у царині ведення здорового способу життя.

У цьому контексті увиразнюється актуальність проблеми розвитку здоров'язбережувальної компетентності студентів технічних спеціальностей в умовах неформальної освіти засобами фізичного виховання.

Аналіз останніх досліджень і публікацій. Проблему удосконалення процесу професійної підготовки фахівців з метою їх орієнтації на формування знань про здоров'я та умінь його зберігати й відновлювати досліджували Ю. Бойчук, Б. Долинський, Ю. Лянной, О. Міхеєнко, М. Носко та ін. Специфіку формування різних аспектів культури здоров'я, здоров'язбереження та здорового способу життя студентів розкривають у своїх дослідженнях Н. Башавець, В. Бондаренко, Д. Воронін, О. Гладощук, Г. Куртова, П. Приходько, А. Сущенко, Л. Сущенко та ін. Концептуальні засади неформальної освіти обгрунтовують у своїх працях В. Андрущенко, О. Аніщенко, Н. Букіна, О. Василенко, Е. Богів, С. Зінченко, Л. Лук'янова, С. Прийма та ін. Теоретичні та методичні засади формування засобів фізичної культури висвітлено у працях В. Бальсевича, Л. Матвєєва, В. Столярова та ін.

Виділення невирішених раніше частин загальної проблеми. Водночас, аналіз стану дослідженості проблеми формування здоров'язбережувальної компетентності студентів технічних спеціальностей в умовах неформальної освіти засобами фізичного виховання дав підстави для висновку щодо недостатності вивчення цього питання у педагогічній теорії й освітній практиці, а відтак потребує теоретичного і практичного осмислення.

Актуальність проблеми посилюється у зв'язку з незадовільним фізичним станом студентської молоді, за даними MO3 значна частина студентів має низький рівень здоров'я i незадовільну фізичну підготовленість. Дефіцит рухової активності студентів складає від $50 \%$ до 70 \%, необхідного для підтримання задовільного стану здоров'я та працездатності. Причинами цього $є$ не тільки соціально-економічні фактори, екологічні проблеми, а й відсутність у студентів пріоритету здоров’я та мотивації щодо здорового способу життя, як основного чинника формування, збереження, зміцнення, відновлення та передачі здоров’я наступним поколінням.

Мета статті полягає в теоретичному обгрунтуванні моделі формування здоров’язбережувальної компетентності студентів технічних спеціальностей в умовах неформальної освіти засобами фізичного виховання. 
Виклад основного матеріалу. Здоров'язбережувальна компетентність майбутніх фахівців технічних спеціальностей - інтегральна динамічна якість особистості, що проявляється в мотивації, потребах та ціннісних орієнтаціях до здорового способу життя, здатності зберігати та реалізовувати власні здоров'язберігаючі позиції, рівень у рівні знань про здоров'я та його складові, способи і методи його збереження, зміцнення та відновлення, у рівні вмінь організувати здоровий спосіб життя й регулювати професійну діяльність, що шкодить здоров'ю в різних, зокрема, несприятливих умовах.

За результатами структурно-логічного аналізу встановлено, що структурними компонентами здоров'язбережувальної компетентності майбутніх фахівців технічних спеціальностей є особистісно-аксіологічний компонент (включає мотиви, цілі, цінності, потреби в здоров'язберженні, стійкий інтерес студента до збереження власного здоров'я та ведення здорового способу життя); гностичний компонент (визначається наявністю у студентів системи знань і уявлень про здоров'язбереження, здоровий спосіб життя); діяльнісний компонент (містить ступінь включення студента в цілісну систему здорового способу життя та в систему здоров'язбереження); поведінковий компонент (містить прагнення до саморозвитку та самовдосконалення у напрямі здоров'язбереження, а також рефлексію ведення зорового способу життя).

За результатами структурно-логічного аналізу категорії «здоров'язбережувальна компетентність майбутніх фахівців технічних спеціальностей» та іï компонентів розроблено діагностичний інструментарій: мотиваційний критерій (показник - мотивація до здорового способу життя, методика оцінки - анкетування), пізнавальний критерій (показник неспеціальна фізкультурна освіченість (за О. Томенком), методика тестування), практичний критерій (показник - оздоровчі уміння, методики індивідуальне дослідне завдання, питальник «Мої дії щодо власного здоров'язбереження»), рефлексивний критерій (показник - рефлексія, методика - анкета оцінки способу життя (за Д. Вороніним)). На основі кількісних параметрів за кожним із показників схарактеризовано три рівні сформованості здоров'язбережувальної компетентності студентів технічних спеціальностей: низький, середній, високий.

Систематизація та узагальнення науково-педагогічних праць (Ю.Бойчук [2], О.Ландо [4], Ю. Лянной [5], О. Міхеєнко [6], М. Носко [7], А.Турчинов [8] та ін.) дають підстави стверджувати, що сучасні науковці вбачають основу здоров'язбереження студентства в змісті дисципліни «Фізичне виховання» $\mathrm{i}$ надають їй особливий функціональний статус серед інших дисциплін (торкається практичної спрямованості й впливу на поведінку людини, привиття навичок оздоровлення та ведення здорового способу життя). Науковці (О. Ажиппо [1], М.Дудчак [3]) наголошують про важливість здоров'я як найвищої загальнолюдської цінності та головного чинника досягнення успіху та благополуччя.

Зазначене дозволяє сприймати здоров'язбережувальну компетентність як 
ключову у фізичному вихованні студентів.

Систематизація та узагальнення науково-педагогічних праць дали підгрунтя стверджувати, що неформальна освіта з фізичного виховання додаткова освіта, що не проводиться в організованому та ієрархічно структурованому контексті (не завершується наданням кваліфікації бакалавр чи магістр з фізичного виховання та видачею загальновизнаного диплому чи атестату, не має тривалості в часі та не базується на державній навчальній програмі), доцільно організована через спортивні секції, відвідування спортивних залів, майданчиків, басейнів, проведення бесід.

Так само як і надання домашніх завдань студентам 3 метою проведення ними самостійних занять фізичними вправами 3 акцентом на підвищення відстаючих фізичних якостей, ведення студентами щоденників, де відображуються показники функціонального стану та фізичної підготовленості, параметри індивідуальних фізичних навантажень та їх спрямованість, створення доступних інформаційних ресурсів 3 проблем оздоровлення, відновлення i підвищення фізичного стану, методик самоконтролю та здорового способу життя, створення методичного кабінету, екскурсії, походи, спортивні ігри, спортивні змагання тощо.

Тому формування здоров'язбережувальної компетентності студентів технічних спеціальностей в умовах неформальної освіти засобами фізичного виховання розглядаємо як спеціально організований i компетентнісно орієнтований процес неформальної освіти, який базується на засобах фізичного виховання і має своїм результатом позитивну динаміку в рівнях сформованості здоров’язбережувальної компетентності, що забезпечує ефективне виконання професійних обов'язків фахівцем технічних спеціальностей.

За методом педагогічного моделювання розроблено модель формування здоров'язбережувальної компетентності студентів технічних спеціальностей в умовах неформальної освіти засобами фізичного виховання (рис. 1).

Нами виокремлено завдання формування здоров'язбережувальної компетентності майбутніх фахівців технічних спеціальностей в умовах неформальної освіти засобами фізичного виховання: оздоровчі завдання (зміцнення здоров'я студентів засобами фізичної рекреації; формування в молодої людини свідомої потреби в підтриманні високого рівня фізичної та розумової працездатності, самоорганізації здорового способу життя).

Додамо ще освітні завдання (оволодіння теоретичними знаннями щодо самостійної організації рухової активності під час дозвілля; оновлення та доповнення теоретичних відомостей щодо впливу засобів фізичного виховання на організм людини; формування системного комплексу знань, теоретичних основ і практичних навичок для реалізації потреби молоді в руховій активності та фізичному вдосконаленні на виробництві; оволодіння новими засобами фізичного виховання); виховні завдання (підвищення рівня фізичної підготовленості; удосконалення психомоторних здібностей, що забезпечують високу продуктивність професійно-технічних дій; створення умов для повної реалізації творчих здібностей студентів; моральне, естетичне, духовне 
удосконалення та подальший розвиток особистості студентів під час дозвілля, організованого засобами фізичного виховання).
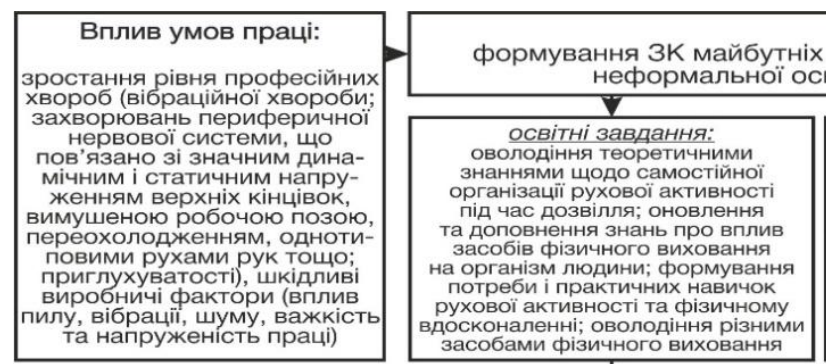

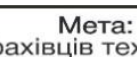
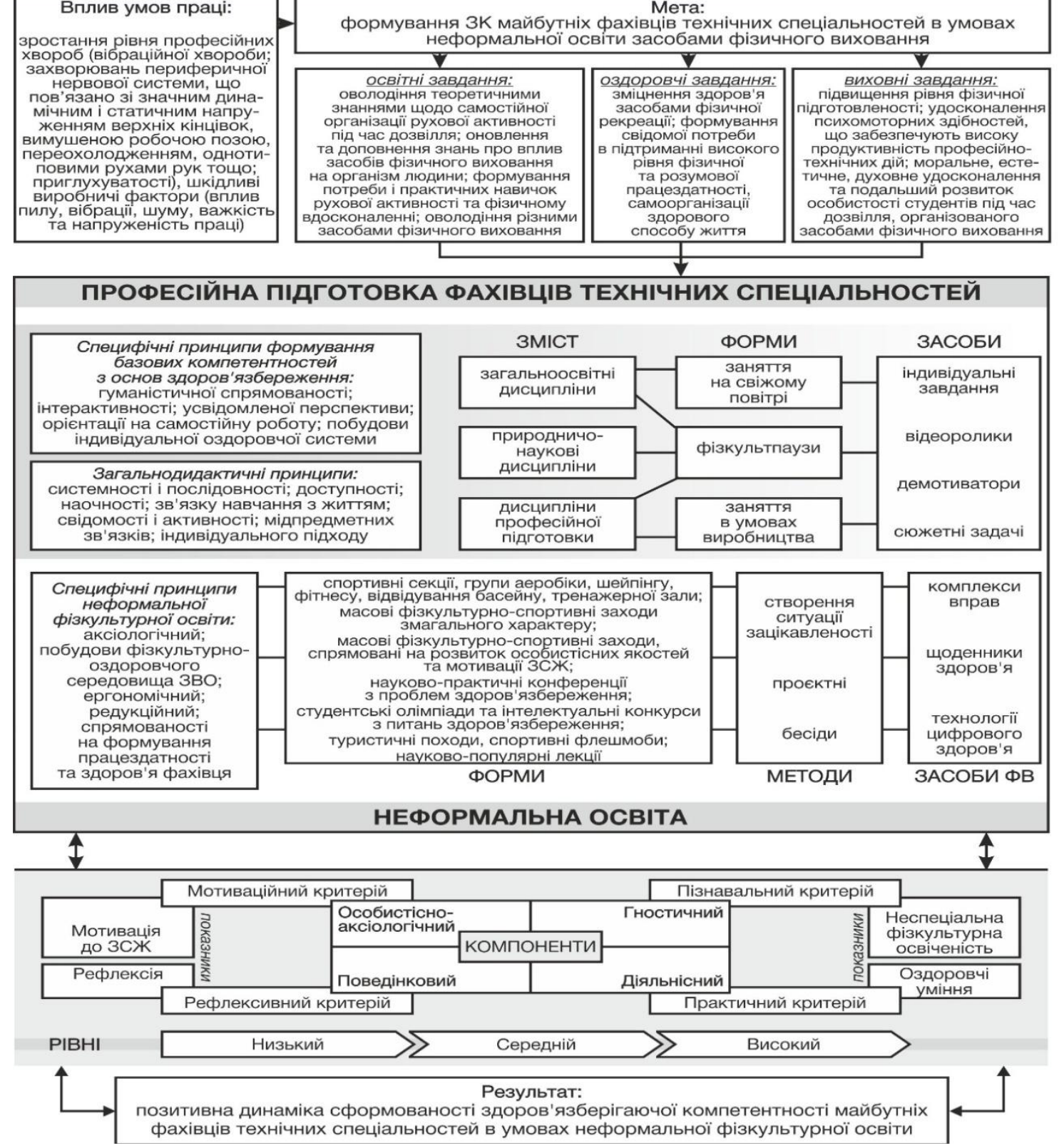

Рис. 1. Модель формування здоров'язбережувальної компетентності студентів технічних спеціальностей в умовах неформальної освіти

В основу формування здоров'язбережувальної компетентності студентів технічних спеціальностей в умовах неформальної освіти засобами фізичного виховання закладено загальнодидактичні принциии (науковості; системності і послідовності; доступності; зв’язку навчання з життям; свідомості і активності; наочності; міцності засвоєння знань, умінь і навичок; індивідуального підходу) і систему специфічних принципів.

А саме: принциипи формування базових компетентностей з основ здоров'язбереження: гуманістичної спрямованості, усвідомленої перспективи, орієнтації на самостійну роботу, інтеграції навчання, інтерактивності, ініціативності, саморегуляційності, побудови індивідуальної оздоровчої 
системи; принципи неформальної фізкультурної освіти: аксіологічний, побудови фізкультурно-оздоровчого середовища ЗВО, ергономічний, редукційний, спрямованості на формування працездатності та здоров'я фахівця.

Реалізація моделі $з$ необхідністю передбачає удосконалення змісту загальноосвітніх, природничо-наукових дисциплін та дисциплін професійної підготовки (вступні лекції з проблем здорового способу життя та впливу професійної діяльності фахівця технічних спеціальностей на стан здоров'я, сюжети текстових задач здоров'язбережувальної тематики). Також нами розроблено програму секційного заняття 3 волейболу, що містить питання здоров'язбережувального спрямування.

Передбачається й використання традиційних та інноваційних методів (створення ситуацій зацікавленості, проєктні методи, бесіди) та засобів (комплекси вправ, щоденники здоров'я, технології цифрового здоров'я) навчання. Серед форм організації діяльності студентів виокремлюємо: фізкультпаузи; спортивні секції, групи аеробіки, шейпінгу, фітнесу, відвідування басейну, тренажерної зали тощо; масові фізкультурно-спортивні заходи («Богатирські ігри», «Ігри патріотів», «Лицарські турніри», «Козацькі забави», «Дні виду спорту», спортивні свята, фестивалі, спартакіади, турніри та ін.) змагального характеру.

Так само як i масові фізкультурно-спортивні заходи (спортивні флешмоби, туристичні походи, масові гуляння 3 нагоди державних та регіональних свят тощо), спрямовані на розвиток особистісних якостей та мотивації до здорового способу життя; науково-практичні конференції для студентської молоді з проблем здоров'язбереження; студентські олімпіади та інтелектуальні конкурси з питань здоров'язбереження.

Результатом реалізації моделі є позитивна динаміка сформованості здоров'язберігаючої компетентності майбутніх фахівців технічних спеціальностей в умовах неформальної фізкультурної освіти.

Висновки. За результатами проведеного аналізу та узагальнення науковометодичних праць встановлено, що використання засобів фізичної культури здоров'язбережувальної спрямованості в межах неформальної освіти не розглядається, водночас потреба у формуванні мотивів та цінностей здорового способу життя, формуванні теоретичних здоров'язбережувальних знань про та вмінь їх використовувати, розвиток прагнення до самовдосконалення у напрямі здоров'язбереження, рефлексії ведення зорового способу життя є важливою для формування професійної компетентності фахівців технічних спеціальностей.

Нами розроблено i теоретично обгрунтовано модель формування здоров'язбережувальної компетентності студентів технічних спеціальностей в умовах неформальної освіти засобами фізичного виховання, яка грунтується на сукупності загальнодидактичних i специфічних принципів та передбачає удосконалення змісту професійної підготовки майбутніх фахівців технічних спеціальностей питаннями здоров'язбереження разом з використанням форм, методів і засобів неформального навчання, які обираються 3 урахуванням напрацювань фізичного виховання у напрямі ведення здорового способу життя. 
Перспективними для подальшого дослідження бачимо розвідки в напрямі формування здоров’язбережувальної компетентності фахівців засобами самонавчання 3 використанням електронних освітніх ресурсів на різних освітніх платформах.

\section{Jimepamypa}

1. Ажиппо О. Ю. Сучасний стан і проблеми індивідуалізованого навчання студентів. Педагогіка формування творчої особистості у вищих $i$ загальноосвітній школах. Запоріжжя : КПУ, 2015. Вип. 42 (95). С. 506-513.

2. Бойчук Ю. Д. Еколого-валеологічна культура майбутнього вчителя : теоретико-методичні аспекти : монографія. Суми : ВТД «Університетська книга», 2008. 357 с.

3. Дутчак М. В. Теоретико-методологічні засади формування системи спорту для всіх в Україні : автореф. дис.... д-ра пед. наук. 13.00.04. Київ : Національний університет фізичного виховання і спорту України, 2009. 38 с.

4. Ландо О. А. Управління формуванням здоров'язбережувальної компетентності майбутніх учителів початкової школи у педагогічних коледжах: автореф. дис. ... канд. пед. наук: 13.00.06. Київ, 2015. 20 с.

5. Лянной Ю.О. Професійна підготовка майбутніх магістрів 3 фізичної реабілітації у вищих навчальних закладах: теоретико-методичний аспект. Суми: СумДПУ імені А.С. Макаренка, 2016. 566 с.

6. Міхеєнко О. Науково-методична система професійної підготовки майбутніх фахівців зі здоров'я людини до застосування здоров'язміцнювальних технологій. Педагогічні науки: теорія, історія, інноваиійні технології. 2016. № 3 (57). C. 222-229.

7. Носко М. О., Гришко Ю. Ю., Носко Ю. М., Дейкун М. П. Руховий розвиток та стан здоров'я школярів та студентів навчальних закладів. Вісник Чернігівського національного педагогічного університету. Серія : Педагогічні науки. 2017. Вип. 142. С. 126-129.

8. Турчинов А. В. Формування здоров'язбережувальної компетентності майбутніх офіцерів національної гвардії України у процесі професійної підготовки : дис. ... канд. пед. наук : 13.00.04. Харків, 2016. 227 с.

\section{References}

1. Azhippo, O.Y. (2015). The current state and problems of individualized student learning. Pedagogy of formation of creative personality in higher and secondary schools, 42 (95), 506 - 513.

2. Boychuk, Y.D. (2008). Ecological and valeological culture of the future teacher: theoretical and methodological aspects. Sumy: VTD "University Book".

3. Dutchak, M.V. (2009). Theoretical and methodological principles of formation of the sports system for all in Ukraine: dis.... dr. ped. science. 13.00.04. Kyiv: National University of Physical Education and Sport of Ukraine.

4. Lando, O.A. (2015). Management of the formation of health-preserving competence of future primary school teachers in pedagogical colleges: dis. ... cand. ped. science: 13.00.06. Kyiv. 
5. Lyannoy, Yu.O. (2016). Professional training of future masters in physical rehabilitation in higher educational institutions: theoretical and methodological aspect. Sumy: Sumy State Pedagogical University named after AS Makarenko.

6. Mikheenko, O. (2016). Scientific and methodological system of professional training of future specialists in human health for the use of health-promoting technologies. Pedagogical sciences: theory, history, innovative technologies, 3 (57), 222-229.

7. Nosko, M.O., Grishko, Yu. Yu., Nosko, Yu. M., \& Deikun, M.P. (2017). Motor development and health status of schoolchildren and students of educational institutions. Bulletin of Chernihiv National Pedagogical University. Series: Pedagogical sciences, 142, 126-129.

8. Turchynov, A.V. (2016). Formation of health-preserving competence of future officers of the National Guad of Ukraine in the process of professional training: dis. ... cand. ped. science: 13.00.04. Kharkiv. 